\title{
KOLABORASI KEPOLISIAN RESOR KOTA PEKANBARU DAN SATPOL PP \\ DALAM MENANGGULANGI PENJUALAN MINUMAN BERALKOHOL \\ OLEH PEDAGANG GEROBAK MOTOR \\ (ANALISIS KEBIJAKAN KRIMINAL)
}

Neri Widya Ramailis, M.Krim

\begin{abstract}
Considering the rampant phenomenon of the trade in alcoholic beverages that are traded in various places by motorbike peddlers especially along the road in Juanda, Pekanbaru City has the potential to add new criminal problems, for example there are indications of abuse of alcoholic beverage use by the buyer (users) especially children and adolescents whose loss of control from family party. Then, people often go to clubs or nightclubs. When they are having a problem or conflict within themselves, they will tend to do things beyond the limits of normal people's thinking, such as drinking excessive alcoholic drinks to get drunk, causing damage and disturbing public order. Fraudulent traders by trading drinks in any place is a phenomenon of crime that leads to the criminal sphere, if viewed from a criminological perspective this phenomenon falls into the category of crime that can interfere with human survival, leading to the disruption of peace, order and peace in the environment Public.
\end{abstract}

Keywords : Police, Civil Service Police Unit, Prevention, Drinks, Alcohol, Criminal Policy.

\section{Pendahuluan}

Pesatnya pertumbuhan

penduduk di Ibu Kota (Provinsi) memberikan nuansa baru bagi lingkungan dan masyarakat yang tinggal atau berdomisili di daerah perkotaan. Maka tidak heran jika kita banyak menjumpai orang-orang yang datang ke kota ini dari berbagai jenis, kalangan dan latarbelakang yang berbeda. Mulai dari etnis, suku, ras, budaya, agama dan profesi. Oleh karena itu tidak bisa dipungkiri bahwa keberagaman yang hadir ditengah masyarakat akan menghasilkan pergerakan dan pola tingkah laku yang berbeda-beda pula di setiap individu masyarakat. 
Laju arus perkembangan zaman dari masa ke masa baik secara langsung maupun tidak langsung menimbulkan dampak negatif terhadap tatanan, nilai-nilai, sistem dan kondisi sosial masyarakat. Misalnya berawal dari life style, gaya hidup yang tidak sehat, sebagai contoh mengkonsumsi minuman berlakohol yang berlebihan bisa membuat seseorang berpotensi menjadi pelaku / korban kejahatan dan penyimpangan.

Sebagaimana dikemukakan oleh Michalowski (1977), berpendapat bahwa kejahatan dapat dipelajari seperti mempelajari gejala alam. Gejala alam dapat dipahami dengan mempergunakan metode ilmiah sebagai hubungan sebabakibat. Hubungan tersebut mengarah pada tingkah laku secara fisikal maupun sosial. Dalam mempelajari kejahatan, aliran pemikiran positivis menempatkan faktor penentunya pada hakikat manusia sebagai individu. Sehingga tingkah laku manusia adalah hasil dari hubungan sebab-akibat antara individu dengan berbagai aspek lingkungannya, dan hubungan tersebut mempunyai kedudukan seperti suatu hukum alam yang berlaku untuk semua orang, sehingga orang yang mempunyai pengalaman yang sama akan cenderung bertingkah laku serupa. Dengan kata lain, teori tentang kejahatan secara apriori dapat dilihat sebagai faktor determinan dengan pendekatan sosial budaya meliputi faktor lingkungan (ekologi), faktor ketiadaan norma (anomi), faktor proses belajar tingkah laku jahat secara sosial, dan faktor pengendalian sosial (Mustofa, 2010 ; 118 - 119).

Pengendalian sosial merupakan reaksi masyarakat atas terjadinya perbuatan antisosial, seperti perilaku menyimpang, tindak kejahatan, pelanggaran, dan kenakalan. Reaksi refresif secara formal dalam melakukan pengendalian sosial, yaitu suatu perbuatan yang dilakukan melalui penegakan hukum yang dilakukan secara formal. Penegakan hukum secara formal dilakukan melalui lembaga penegakan hukum yang diberikan mandat oleh masyarakat, untuk bertindak dan memproses para pelaku melalui hukum. Penegakan hukum dilakukan melalui sistem hukum yang berlaku, yaitu sistem peradilan pidana (criminal justice system), yang terdiri dari berbagai macam unsur penegak hukum seperti kepolisian, kejaksaan, 
pengadilan, dan lembaga pemasyarakatan (Hisyam, 2018 ; 3).

$$
\text { Mengingat maraknya }
$$

fenomena perdagangan minuman beralkohol yang diperjualbelikan disembarang tempat oleh pedagang keliling gerobak motor khususnya di sepanjang jalan juanda kota pekanbaru berpotensi menambah persoalan kriminalitas baru, sebagai contoh adanya indikasi penyalahgunaan pemakaian minuman beralkohol oleh si pembeli (pengguna) terutama anak dan remaja yang loss kontrol dari pihak keluarga (broken familly).

\section{Permasalahan}

Jika di lihat dari defenisi minuman beralkohol adalah minuman yang mengandung etanol. Di mana etanol adalah bahan psikoaktif dan konsumsinya menyebabkan penurunan kesadaran. Dalam minuman alkohol sendiri merupakan bahan utama dengan kadar yang bermacam-macam, misalnya: whisky, brandy, bir, dan juga anggur dalam minuman tradisional (Wresniwirro, 1995:7).

Adapun standarisasi minuman beralkohol sesuai dengan Keputusan Menteri Kesehatan Nomor:
282/MENKES/SK/II/1998 Tentang standar mutu produksi minuman keras di bagi menjadi 3 golongan, yaitu:

1. Golongan A Minuman Beralkohol dengan kadar etanol $(\mathrm{C} 2 \mathrm{H} 5 \mathrm{OH}) 1 \%$ sampai dengan $5 \%$

2. Golongan B Minuman Beralkohol dengan kadar etanol $(\mathrm{C} 2 \mathrm{H} 5 \mathrm{OH})$ lebih dari 5\% sampai dengan $20 \%$

3. Golongan $\mathrm{C}$ Minuman Beralkohol dengan kadar etanol (C2H5OH) 20\% sampai dengan 55\% (Margiyani,Lusi.2001:23)

Berdasarkan Undang-Undang nomor 11 Tahun 1995, minuman beralkohol merupakan produk yang dibatasi dan diawasi peredarannya dan hal tersebut juga diatur dalam Keputusan Presiden Republik Indonesia nomor 3 Tahun 2007 tentang pengawasan dan pengendalian minuman beralkohol.

Begitu banyak kecurangan dilakukan pedagang dalam berjualan, mulai dari menjual secara illegal, di oplos, bahkan diperjualbelikan secara bebas tanpa menghiraukan batasan umur pembeli. Akan tetapi sebagaimana diatur dalam pasal 14 ayat 1.2 dan ayat 
3 Pemendag 20/2014 hanya dapat diberikan kepada konsumen yang telah berusia 21 (dua Puluh satu) tahun atau lebih dengan menunjukan identitas kepada petugas/pramuniaga.

Kecurangan para pedagang dengan memperjualabelikan minuman di sembarang tempat adalah merupakan suatu fenomena tindak kejahatan yang mengarah pada ranah pidana, jika ditinjau dari perspektif kriminologi fenomena ini termasuk ke dalam kategori kejahatan yang dapat mengganggu keberlangsungan hidup manusia, mengarah pada terganggunya ketentraman, ketertiban dan kedamaian di lingkungan masyarakat.

Sebagai negeri yang dijuluki Bumi Lancang Kuning Kota Bertuah, dimana masyarakat sangat memegang teguh dan menjunjung tinggi nilai-nilai, adat dan budaya melayu sudah sepatutnya kita peduli terhadap kondisi yang dapat merusak tatanan lingkungan masyarakat..

Persoalan ini tidak bisa di diamkan begitu saja oleh penegak hukum (kepolisian) karena ini merupakan tugas dan tanggungjawab utama mereka dalam memberantas tindak kejahatan dan penyimpangan sosial di negeri ini. Adapun Peran dan tugas pokok Polisi Republik Indonesia (Polri) sebagaimana diatur dalam pasal 13 Undang-undang Nomor 2 tahun 2002 tentang Kepolisian Negara Republik Indonesia (UU KNRI) meliputi: (1) Memelihara Keamanan dan Ketertiban Masyarakat (Kamtibmas), (2) Menegakkan Hukum, dan (3) Memberikan Perlindungan. Pengayoman dan Pelayanan Masyarakat. Secara universal, tugas pokok lembaga kepolisian mencakup dua hal yaitu Pemeliharaan Keamanan dan Ketertiban (Peace and order maintenance) dan Penegakan Hukum (law enforcement). (Prayogi.2016:4)

Selanjutnya pengawasan dan pengendalian sebelumnya telah diatur oleh Peraturan Mentri Perdagangan Republik Indonesia Nomor 20/MDag/Per/4/2014 Tahun 2014 tentang pengendalian dan pengawasan terhadap pengadaan, peredaran, dan penjualan minuman beralkohol yang diubah dengan Peraturan Mentri Perdagangan Republik Indonesia Nomor 72/MDag/Per/10/2014 tahun 2014.

Polisi sebagai aparatur Negara dalam hal penegakan hukum memiliki kedudukan dan peranan yang sangat 
penting yaitu sebagai pemelihara keamanan, dalam implementasinya ialah mencegah dan menanggulangi suatu tindak kejahatan serta pelanggaran sebagai pengayom masyarakat dengan menjalankan tugas dan fungsinya yang bersifat preventif maupun represif. Pada aspek preventif yaitu melakukan upaya pencegahan sebelum kejahatan terjadi agar tindak kejahatan tidak terjadi dengan adanya dukungan serta partisipasi aktif dari masyarakat. Kemudian, apabila upaya pencegahan gagal maka polisi mengambil langkah yang bersifat represif yaitu upaya penanggulangan setelah kejahatan terjadi.

Dengan adanya Peraturan Daerah Nomor 14 tahun 2006 tentang Retribusi Izin Usaha Perdagangan Minuman Beralkohol, yang melarang peredaran minuman beralkohol di kota pekanbaru, maka dalam pelaksanaan penertibannya dapat dilakukan dengan instansi terkait yang sudah ditunjuk oleh kepala daerah sehingga perlu upaya atau peran dari Kepolisian dan anggota Satpol PP (Satuan Pamong Praja) untuk menanggulangi atau meminimalisir penjualan minuman beralkohol dikota pekanbaru sehingga dapat mencegah hal-hal lain yang dapat menimbulkan keresahan di masyarakat.

\section{Perspektif Kebijakan Kriminal (Penal Policy)}

Istilah kebijakan kriminal atau yang disebut penal policy (Inggris). Ungkapan ini lebih sempit apabila diperbandingkan dengan criminal (law) policy atau kebijakan hukum pidana. Di samping dapat dilakukan secara refresif melalui sistem peradilan pidana (pendekatan penal) dapat pula dilakukan dengan cara "non penal" melalui usaha pencegahan tanpa melibatkan sistem peradilan pidana, misalnya usaha penyehatan mental masyarakat, penyuluhan hukum, pembarun hukum perdata serta hukum administrasi. dalam konteks ini pencegahan kejahatan pada dasarnya merupakan tujuan utama dari kebijakan kriminal.

Hoefnagels menjelaskan defenisi kebijakan kriminal dalam empat kategori sebagai berikut :

1. Criminal policy is the science of responses (kebijakan kriminal merupakan ilmu-ilmu tentang respon atau tanggapan terhadap kejahatan). 
2. Criminal policy is the sciences of crime prevention (kebijakan kriminal sebagai ilmu-ilmu berkaitan dengan pencegahan kejahatan).

3. Criminal policy is a policy of designating human behavior as crime (kebijakan kriminal sebagai kebijakan dalam menentukan perbuatan manusia sebagai kejahatan).

4. Criminal policy is a rational total of the responses of crime (kebijakan kriminal sebagai rasionalitas yang menyeluruh tentang tanggapan-tanggapan (masyarakat terhadap kejahatan).

Hoefnagels menyatakan kebijakan kriminal merupakan suatu ilmu tentang kebijakan dalam arti yang lebih luas, yakni kebijakan penegakan hukum, kebijakan perundang-undangan (legislatif) dan penegakan hukum yang pada gilirannya akan menjadi bagian dari kebijakan sosial.

Istilah kebijakan sebagaimana telah dikemukakan di atas, berasal dari polities (Inggris) atau dalam bahasa Belanda : politiek, yang mengandung arti sesuatu yang berkaitan dengan negara. Dengan demikian, pembicaraan tentang kebijakan atau policy berarti membicarakan masalah kenegaraan atau yang berhubungan dengan negara. Berdasarkan hal demikian Soedarto menyatakan bahwa yang dimaksut dengan politik hukum ialah kebijakan dari negara melalui badan-badan yang berwenang untuk menetapkan peraturan-peraturan yang dikehendaki yang diperkirakan bisa digunakan (Zaidan, 2016 : 262-266).

\section{Teori Penanggulangan dan} Pencegahan Kejahatan

Penanggulangan dan pencegahan terhadap kejahatan merupakan cara masyarakat bereaksi terhadap fenomena kejahatan. Rasionalitas dalam penepatan jenisjenis sanksi merupakan pencerminan tarif ilmu pengetahuan dan kebudayaan suatu bangsa. Peranan badan legislasi yang diberi tugas menyusun undangundang membawa perubahan yang signifikan, yakni beralihnya "kewenangan" untuk bereaksi terhadap kejahatan yang semula merupakan ranah masyarakat untuk menetukannya. Undang-undang dapat dipanddang sebagai cara masyarakat dalam 
merespon kejahatan. Peraturan perundang-undangan di bidang hukum pidana merupakan cara yang dibangun oleh masyarakat untuk memperlakukan kejahatan dan penjahat. Dengan demikian, perkembangan masyarakat telah terjadi sedemikian rupa sehingga pelanggar hukum tidak bisa di perlakukan dengan sewenang-wenang.

dapat di bagi dalam tiga kelempok berikut :

1. Respon yang bersifat non formal yang dilakukan oleh masyarakat sendiri dari cara lunak hingga cara kasar seperti tindakan main hakim sendiri.

2. Respon yang bersifat informal dilakukan dalam bentuk teguran atau peringatan terhadap orangorang yang diduga melakukan pelanggaran hukum.

3. Respon yang bersifat formal, metode yang digunakan untuk melawan kejahatan dilakukan secara formal melalui sistem paradilan pidana.

Upaya penanggulangan kejahatan merupakan kebijakan integral yang terkait satu sama lain yaitu kebijakan sosial, kebijakan kriminal dan kebijakan hukum pidana, untuk mencapai kesejahteraan masyarakat. Kebijakan kriminal (Criminal Policy) atau politik kriminal adalah suatu usaha rasional untuk menangulangi kejahataan. Politik kriminal ini merupakan bagian dari politik penegakan hukum dalam arti luas (Law Enforcement Policy) merupakan bagian dari politik sosial (Sosial Policy) yakni usaha dari masyarakat untuk meningkatkan kesejahteraannya (Hermasnyah, 2013:184).

Menurut G.P. Hoefnagels yang dikutip oleh Barda Nawawi Arief (2011: 45), upaya penangulangan kejahatan dapat ditempuh dengan:

1. Penerapan hukum pidana (criminal law application);

2. Pencegahan tanpa pidana (prevention without punishment);

3. Mempengaruhi pandangan masyarakat mengenai kejahatan dan pemidanaan lewat mass media (influencing views ofsociety on crime and punishment / mass media).

Penanggulangan kejahatan dapat dilakukan dengan menggunakan sarana Non Penal dan sarana Penal. 
Berdasarkan pendapat yang dikemukakan oleh G.P. Hoefnagels yang dikutip oleh Barda Nawawi Arif upaya penanggulangan kejahatan secara garis besar dapat dibagi menjadi dua yakni :

\section{Jalur Penal}

Upaya penanggulangan lewat jalur penal ini bisa juga disebut sebagai upaya yang dilakukan melalui jalur hukum pidana. Upaya ini merupakan upaya penindakan yang ditujukan ke arah penangkapan semua kasus tindak pidana yang telah terjadi yang menitikberatkan pada sifat represif seperti penegakan hukum dan penjatuhan hukuman sebagai penindasan, pemberantasan juga penumpasan terhadap kejahatan yang telah dilakukan (Raharjo, 2014:3).

2. Jalur Non-Penal

Upaya penanggulangan lewat jalur non-penal ini bisa juga disebut sebagai upaya yang dilakukan melalui jalur di luar hukum pidana. Upaya ini merupakan upaya penanggulangan yang lebih menitik beratkan pada sifat preventif, yakni tindakan yang berupa pencegahan sebelum terjadinya kejahatan yang merupakan kebijakan paling strategis. Melalui upaya non- penal ini sasaran utamanya adalah menangani faktor-faktor kondusif penyebab terjadinya kejahatan, yakni meliputi masalah-masalah atau kondisikondisi sosial yang secara langsung atau tidak langsung dapat menimbulkan atau menumbuhsuburkan kejahatan. Jalur non penal meliputi berbagai cara bisa berupa kampanye atau sosialisasi kepada masyarakat melalui lembaga yang terkait dan juga sebagai pencegahan, penangkalan dan pengendalian. Selain itu bisa melalui pendekatan teknologi, budaya, atau kultural, moral atau eduktif, global atau kerja sama ilmiah atau internasional, pendidikan agama (Quia, 2015:649).

a. Pencegahan tanpa pidana (prevention without punisment), termasuk di dalamnya penerapan sanksi administratif dan sanksi perdata,

b. Mempengaruhi pandangan Masyarakat mengenai kejahatan dan pembinaan lewat media massa (influencing views of society on crime and punishment).

Upaya penanggulangan kejahatan lewat jalur "penal" lebih 
menitik beratkan pada sifat "repressive" (penindasan/ pemberantasan/ penumpasan) sesudah kejahatan terjadi, sedangkan jalur "non-penal" lebih menitik beratkan pada sifat "preventif" (pencegahan/ penangkalan pengendalian) sebelum kejahatan terjadi (Ummah, 2017:2).

\section{Metode Penelitian}

Penelitian ini merupakan penelitian mixed method atau gabungan dengan menggunakan metode kualitatif dan visual kriminologi. Pada dasarnya metode visual merupakan metode penelitian dengan menggunakan perangkat visual seperti dengan mengumpulkan gambar (foto) sebagai bukti data otentik yang ditemukan dilapangan.

Metode visual telah terlebih dahulu dikembangkan dalam study antropology visual dan sosiologi visual. Cecil Greek (2005 ; 3) dalam tulisannya Visual Criminology : using Photography (and videography) as an Ethnographic Reseach Metod in Criminal Justice Setting menjelaskan : visual kriminologi merupakan aspek penting dalam kajian kriminologi, terutama dalam menggambarkan aspek realitas dan menangkap makna dari fenomena sosial melalui fotografi dan videografi. 
Model Analisa

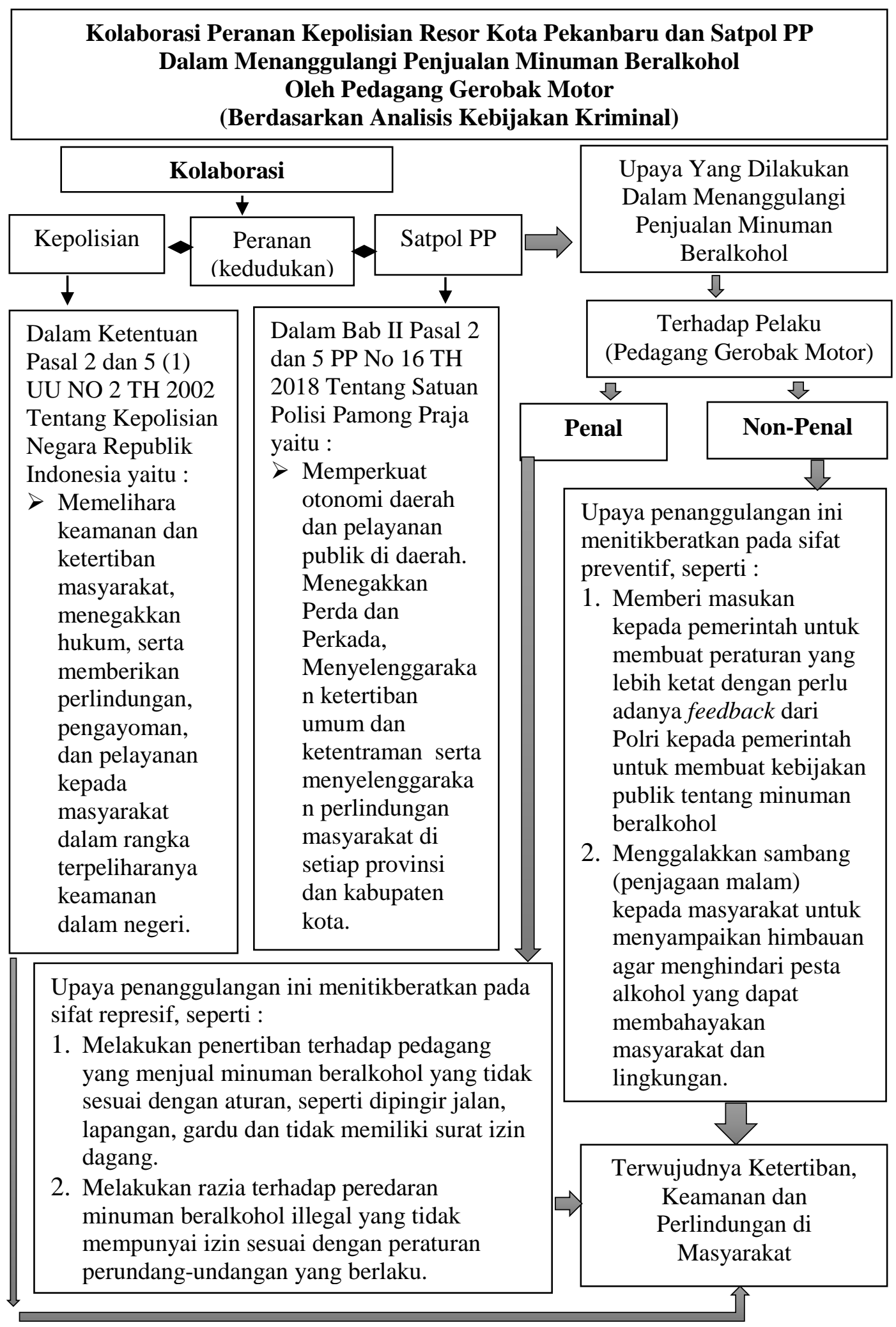

Sumber : Modifikasi Penulis Tahun 2019 


\section{Temuan Penelitian}

\section{Visualisasi Razia Minuman}

\section{Beralkohol oleh Polresta dan}

\section{Satpol PP Kota Pekanbaru}

Berdasarkan hasil observasi

dan pengamatan langsung di lokasi penelitian, penulis memperoleh beberapa gambaran kegiatan yang dilakukan oleh ke dua institusi yakni Kepolisian Resor Kota Pekanbaru dan Satpol PP dalam menanggulangi penjualan minuman beralkohol. Berikut adalah visualisasi razia yang dilakukan oleh pihak Polresta Pekanbaru di salah satu warung remang-remang yang ada di Jalan Arengka.

Tabel Gambar. 1

Visualisasi Razia Minuman Beralkohol Oleh Polresta Pekanbaru

\begin{tabular}{|c|c|c|}
\hline Gambar & Keterangan & Tempat \& Waktu \\
\hline Gambar 1: & $\begin{array}{l}\text { Anggota Polresta } \\
\text { Pekanbaru saat } \\
\text { melaksanakan razia } \\
\text { cipta kondisi di } \\
\text { jalan arengka }\end{array}$ & $\begin{array}{l}\text { Lokasi kejadian : } \\
\text { Warung remang- } \\
\text { remang jalan } \\
\text { arengka } \\
\text { Waktu kejadian : } \\
\text { Senin, } 23 \text { April } 2018 \\
\text { Pukul, 02.00 Wib }\end{array}$ \\
\hline Gambar 2: & $\begin{array}{l}\text { Anggota Polresta } \\
\text { Pekanbaru saat } \\
\text { melaksanakan razia } \\
\text { cipta kondisi di } \\
\text { jalan arengka }\end{array}$ & $\begin{array}{l}\text { Lokasi kejadian : } \\
\text { Warung remang- } \\
\text { remang jalan } \\
\text { arengka } \\
\text { Waktu kejadian : } \\
\text { Senin, } 23 \text { April } 2018 \\
\text { Pukul, } 02.00 \text { Wib }\end{array}$ \\
\hline
\end{tabular}


Tabel Gambar. 2

Visualisasi Razia Minuman Beralkohol Oleh Satpol PP Kota Pekanbaru

\begin{tabular}{|l|l|l|}
\hline \multicolumn{1}{|c|}{ Gambar } & \multicolumn{1}{|c|}{ Keterangan } & Tempat \&Waktu \\
\hline Gambar 1: & $\begin{array}{l}\text { Keterangan : } \\
\text { Anggota Satpol PP } \\
\text { kota Pekanbaru } \\
\text { melaksanakan razia } \\
\text { di warung remang- } \\
\text { remang simpang } \\
\text { palas rumbai. }\end{array}$ & $\begin{array}{l}\text { Lokasi kejadian : } \\
\text { Warung remang- } \\
\text { remang jalan } \\
\text { Simpang Palas } \\
\text { Rumbai }\end{array}$ \\
& $\begin{array}{l}\text { Waktu kejadian : } \\
\text { Jum'at, 16 Agustus } \\
\text { 2019 } \\
\text { Pukul, 23.00 Wib }\end{array}$ \\
\hline & $\begin{array}{l}\text { Anggota Satpol PP } \\
\text { melakukan } \\
\text { pengecekan Izin } \\
\text { usaha di salah satu } \\
\text { tempat hiburan di } \\
\text { Kota Pekanbaru }\end{array}$ & $\begin{array}{l}\text { Lokasi kejadian : } \\
\text { New Paragon jl. } \\
\text { Sultan syarif kasim } \\
\text { Waktu kejadian : } \\
\text { Kamis, 28 Juni 2018 } \\
\text { Pukul, 00:30 Wib }\end{array}$ \\
\hline
\end{tabular}

Tabel Gambar. 3

Visualisasi Pemusnahaan Minuman Beralkohol Oleh Polresta Pekanbaru

\begin{tabular}{|c|c|c|}
\hline Gambar & Keterangan & Tempat \& Waktu \\
\hline Gambar 1: & $\begin{array}{l}\text { Konferensi pers } \\
\text { hasil penangkapan } \\
\text { sejumlah } 2.092 \\
\text { Botol minuman } \\
\text { beralkohol di kota } \\
\text { pekanbaru yang di } \\
\text { lakukan oleh } \\
\text { Polresta. }\end{array}$ & $\begin{array}{l}\text { Lokasi kejadian : } \\
\text { Polresta Pekanbaru } \\
\text { Waktu kejadian : } \\
\text { Selasa, 29 April } \\
\text { 2018 } \\
\text { Pukul, 09:00 Wib }\end{array}$ \\
\hline Wust & $\begin{array}{l}\text { Polda Riau \& } \\
\text { Polresta Pekanbaru } \\
\text { melakukan } \\
\text { Pemusnahan hasil } \\
\text { penangkapan } \\
\text { Narkotika dan } \\
\text { Miras di halaman } \\
\text { kantor Gubernur } \\
\text { Riau. }\end{array}$ & $\begin{array}{l}\text { Lokasi kejadian : } \\
\text { Halaman Depan } \\
\text { Kantor Gubernur } \\
\text { Riau } \\
\text { Waktu kejadian : } \\
\text { Jum'at, } 21 \\
\text { Desember } 2018 \\
\text { Pukul, 09:00 Wib }\end{array}$ \\
\hline
\end{tabular}




\begin{tabular}{|l|l|l|}
\hline Gambar 3: & $\begin{array}{l}\text { Minuman Keras di } \\
\text { musnahkan dengan } \\
\text { menggunakan Alat } \\
\text { Berat. }\end{array}$ & $\begin{array}{l}\text { Lokasi kejadian : } \\
\text { Halaman Depan } \\
\text { Kantor Gubernur } \\
\text { Riau }\end{array}$ \\
& & Waktu kejadian : \\
& & Jum'at, 21 \\
& Desember 2018 \\
& & Pukul, 09:00 Wib \\
\hline
\end{tabular}

Terkait pemusnahan yang di rutin di tempat hiburan malam, lakukan oleh berbagai instansi warung atau cafe remang-remang termasuk Polresta dan Satpol PP yang tidak memiliki izin usaha yang Kota Pekanbaru terhadap ada di Kota Pekanbaru, pemusnahan penanggulangan penjualan minuman tersebut di lakukan di depan kantor beralkohol di Kota Pekanbaru yaitu Gubernur Riau pada bulan Desember berupa pemusnahan barang bukti akhir tahun 2018.

yang di dapat saat melakukan razia

Tabel Gambar. 4

Visualisasi Gerobak Motor Tempat Dagangan Minuman Beralkohol

\begin{tabular}{|c|c|c|}
\hline Gambar & Keterangan & Tempat Waktu \\
\hline Gambar 1 : & $\begin{array}{l}\text { Suasana jalan } \\
\text { Juanda pada siang } \\
\text { hari }\end{array}$ & $\begin{array}{l}\text { Lokasi kejadian : } \\
\text { Jl. Juanda } \\
\text { Waktu kejadian : } \\
\text { Jumat, } 28 \text { Agustus } \\
\text { 2019 } \\
\text { 11:00 Wib }\end{array}$ \\
\hline$\sqrt{4}$ & $\begin{array}{l}\text { Kondisi di malam } \\
\text { hari pedagang } \\
\text { minuman } \\
\text { beralkohol menjual } \\
\text { dagangan dengan } \\
\text { menggunakan } \\
\text { gerobak motor di } \\
\text { jalan Juanda }\end{array}$ & $\begin{array}{l}\text { Lokasi kejadian : } \\
\text { Jl. Juanda } \\
\text { Waktu kejadian : } \\
\text { Jumat, } 28 \text { Agustus } \\
\text { 2019 } \\
\text { 20:00 Wib }\end{array}$ \\
\hline
\end{tabular}




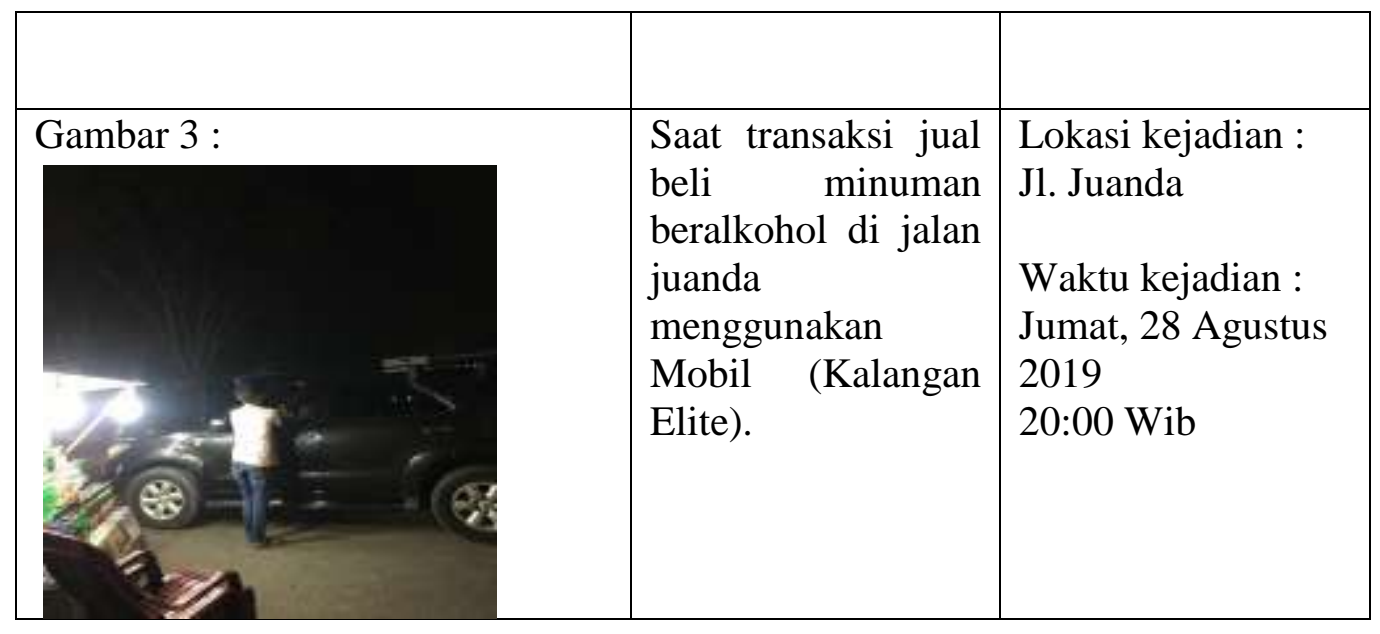

Tabel Gambar. 5

Visualisasi Jenis Minuman Beralkohol yang Di Jual di Jalan Juanda

\begin{tabular}{|c|c|c|}
\hline Gambar & Keterangan & Tempat \& Waktu \\
\hline Gambar 1 : Jack Daniel's & $\begin{array}{l}\text { Minuman alkohol } \\
\text { ini berasal dari } \\
\text { negeri Pamansam } \\
\text { yaitu Amerika } \\
\text { Serikat dengan } \\
\text { kadar alkohol } 40 \% \\
\text { dan di jual dengan } \\
\text { harga berkisar Rp. } \\
550.000\end{array}$ & $\begin{array}{l}\text { Lokasi kejadian : } \\
\text { Jl. Juanda } \\
\text { Waktu kejadian : } \\
\text { Jumat, } 28 \text { Agustus } \\
\text { 2019 } \\
\text { 20:00 Wib }\end{array}$ \\
\hline & \begin{tabular}{lrr} 
Minuman & \multicolumn{2}{c}{ alkohol } \\
dari Perancis & ini \\
memiliki & kadar \\
alkohol & 40 & $\%$ \\
dengan & harga & dan \\
ukuran & & yang \\
bervariasi & mulai dari \\
ukuran & $(\mathrm{S})$ & Rp. \\
65.000 & & $(\mathrm{M})$ \\
Rp.300.000 & (L) & Rp. \\
500.000. & &
\end{tabular} & $\begin{array}{l}\text { Lokasi kejadian : } \\
\text { Jl. Juanda } \\
\text { Waktu kejadian : } \\
\text { Jumat, } 28 \text { Agustus } \\
\text { 2019 } \\
\text { 20:00 Wib }\end{array}$ \\
\hline 10 & $\begin{array}{lr}\text { Minuman } & \text { Alkohol } \\
\text { dari Puerto Rico ini } \\
\text { memiliki kadar } \\
\text { alkohol } 35 \% \text { dengan } \\
\text { varian Original } \\
\text { Spiced Gold seharga } \\
\text { Rp. 350.000 dan } \\
\text { Captain Morgan }\end{array}$ & $\begin{array}{l}\text { Lokasi kejadian : } \\
\text { Jl. Juanda } \\
\text { Waktu kejadian : } \\
\text { Jumat, } 28 \text { Agustus } \\
\text { 2019 } \\
\text { 20:00 Wib }\end{array}$ \\
\hline
\end{tabular}




\begin{tabular}{|c|c|c|}
\hline & $\begin{array}{lr}\text { White } & \text { Room } \\
\text { seharga Rp. } & 320.000 \\
\end{array}$ & \\
\hline 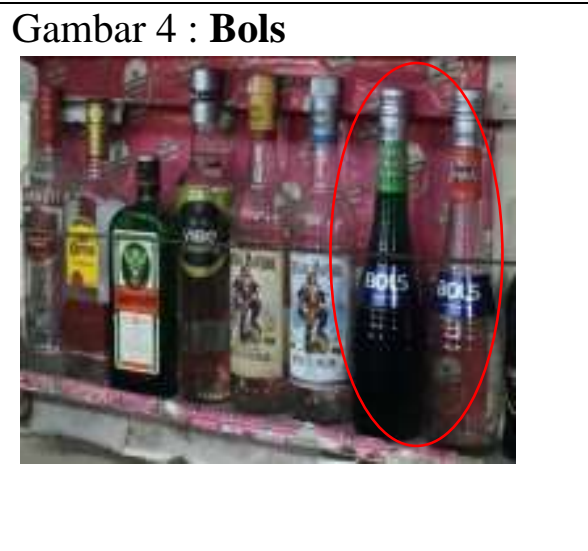 & $\begin{array}{l}\text { Minuman Alkohol } \\
\text { dari Argentina } \\
\text { memiliki kadar } \\
\text { alcohol } 40 \% \\
\text { dengan varian Paper } \\
\text { mint Green dan } \\
\text { cherry Brundy } \\
\text { dengan ukuran } 750 \\
\text { Ml seharga } \\
\text { Rp.550.000 }\end{array}$ & $\begin{array}{l}\text { Lokasi kejadian : } \\
\text { J1. Juanda } \\
\text { Waktu kejadian : } \\
\text { Jumat, } 28 \text { Agustus } \\
\text { 2019 } \\
\text { 20:00 Wib }\end{array}$ \\
\hline Gambar 5: & $\begin{array}{l}\text { Minuman Alkohol } \\
\text { yang berasal dari } \\
\text { Jerpan yang } \\
\text { memiliki kadar } \\
\text { alkohol } 35 \% \\
\text { dengan ukuran } 750 \\
\text { Ml seharga } \\
\text { Rp } 520.000\end{array}$ & $\begin{array}{l}\text { Lokasi kejadian: } \\
\text { J1. Juanda } \\
\text { Waktu kejadian : } \\
\text { Jumat, } 28 \text { Agustus } \\
\text { 2019 } \\
\text { 20:00 Wib }\end{array}$ \\
\hline 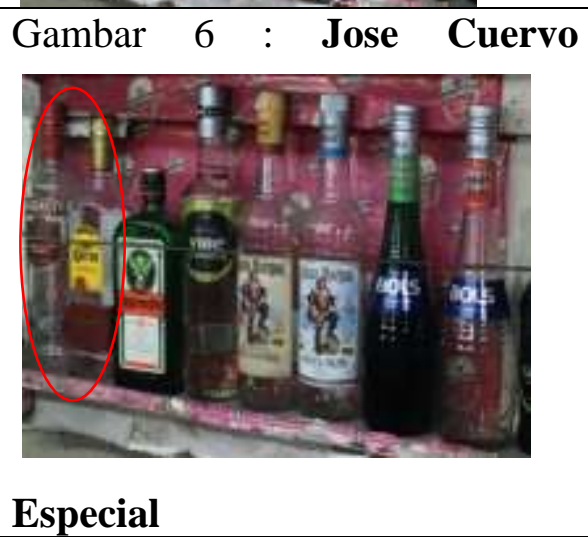 & $\begin{array}{l}\text { Minuman Alkohol } \\
\text { yang berasal dari } \\
\text { Meksiko ini yang } \\
\text { memiliki kadar } \\
\text { alcohol } 35 \% \\
\text { dengan ukuran } 750 \\
\text { Ml seharga Rp. } \\
450.000\end{array}$ & $\begin{array}{l}\text { Lokasi kejadian : } \\
\text { J1. Juanda } \\
\text { Waktu kejadian : } \\
\text { Jumat, } 28 \text { Agustus } \\
\text { 2019 } \\
\text { 20:00 Wib }\end{array}$ \\
\hline
\end{tabular}

\section{Analisa Penelitian}

Di lihat dari beberapa hasil wawancara dengan narasumber dan berdasarkan hasil dokumentasi visual yang di peroleh saat melakukan penelitian maka tergambar bahwa tidak ada terjalin bentuk kolaborasi (kerjasama) terutama terkait peranan yang dilakukan oleh kedua institusi penegak hukum yakni antara anggota 
Kepolisian Resor Kota Pekanbaru dan anggota Satpol PP terhadap penanggulangan perdagangan minuman beralkohol yang dilakukan oleh pedagang gerobak motor.

Penegak hukum di Kota Pekanbaru terkesan tidak serius dan tidak tegas dalam mencegah dan menanggulangi fenomena kejahatan dan penyimpangan yang terjadi. Sebagai contoh dari petikan wawancara dengan anggota Satpol PP, kegiatan yang mereka jalankan hanya sekedar melakukan razia rutin izin usaha, tempat hiburan malam, cafe ataupun warung remangremang. Sedangkan untuk penanggulangan terhadap gerobak motor dan ruko-ruko di jalan juanda ataupun daerah tangor tidak pernah di lakukan razia atau pun di geledah oleh pihak Poresta Pekanbaru, Satpol PP, Polsek setempat ataupun instansi lainnya.

Tidak adanya tindakan lebih lanjut dari setiap peranan dan upaya yang dilakukan oleh kedua lembaga ini apakah sifatnya kerjasama dalam hal memelihara keamanan dan ketertiban masyarakat, menegakkan hukum, serta memberikan perlindungan, pengayoman, dan pelayanan kepada masyarakat dalam rangka terpeliharanya keamanan maka tidak heran jika peredaran minuman beralkohol sangat berkembang pesat di kota pekanbaru karena tidak efektifnya fungsi pengawasan ataupun penindakan terhadap pelaku usaha / pedagang yang memperjualbelikan minuman haram tersebut.

Jika di tinjau dari hasil wawancara dengan warga / masyarakat yang tinggal dan menjalankan usaha disekitar lokasi penelitian ini berdasarkan keterangannya menjelaskan bahwa mereka sudah biasa melihat orang membeli minuman ini ke warung / toko tersebut mulai dari anak remaja sampai orang dewasa. Nah biasa nya kalau untuk orang atau pembeli baru dan orang ini terlihat asing belum pernah datang ke daerah tersebut biasanya mereka tidak mau secara terang-terangan memberikan informasi mengenai barang ini ada atau tidaknya dijual di toko itu. Jika ada yang bertanya biasanya mereka mengarahkan pada salah satu orang perantara, dari situlah nanti baru 
pembeli bisa mendapatkan minuman beralkohol.

$$
\text { Lebih lanjut seorang }
$$

budayawan Provinsi Riau Datuk Nasir Panyalai, menjelaskan di dalam budaya adat melayu peredaran minuman beralkohol secara komersial termasuk pada kategori perbuatan yang salah dan melenceng dari ajaran agama yang mana falsafah orang melayu berpedoman pada "Adat Bersendi Sara", Sara" Bersendikan Kitabullah". Terlebih lagi icon Pekanbaru sebagai Kota Madani tidak cocok dengan kultur dan adat - istiadat kita yang identik dengan nilai-nilai ke-islaman.

\section{Kesimpulan}

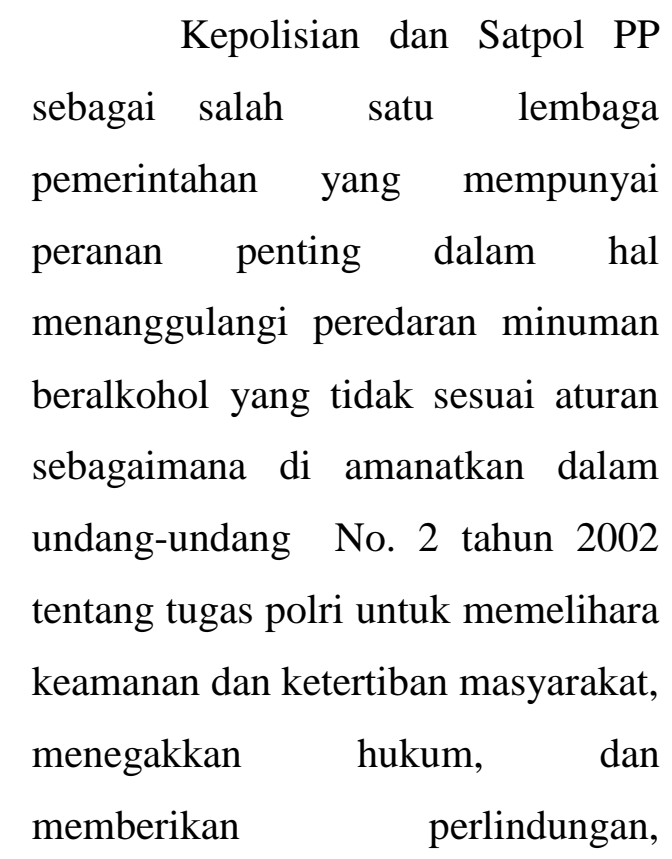

pengayoman, dan pelayanan kepada masyarakat. Begitu juga sebaliknya dengan Satpol PP yang telah di amanatkan dalam Peraturan Pemerintah No. 16 Tahun 2018 tentang tugas Satpol PP yang dibentuk untuk menegakkan Peraturan Daerah dan Peraturan Kepala Daerah, menyelenggarakan ketertiban umum dan ketentraman serta menyelenggarakan perlindungan masyarakat. Akan tetapi pada kenyataan di lapangan tugas dan wewenang tersebut tidak sepenuhnya di lakukan sehingga keamanan dan ketertiban tidak tercapai dengan baik.

Realitasnya tidak ada terjalin kerjasama terkait kolaborasi terutama dalam menjalankan peranan sebagai lembaga penegakan hukum yakni dari pihak Polresta Pekanbaru dengan Satpol PP dalam menanggulangi penjualan minuman beralkohol yang dilakukan oleh pedagang gerobak motor. Polresta dan Satpol PP hanya melakukan razia di warung remang-remang dan tempat hiburan malam yang ada di Pekanbaru. Kemudian, penanggulangan terhadap pedagang 
minuman beralkohol yang melakukan penindakan terhadap menggunakan kendaraan gerobak penjual minuman beralkohol dengan motor sama sekali tidak tersentuh menggunakan gerobak motor dengan dalam kegiatan razia yang di beralasan karena tidak ada undanglakukan oleh pihak Polresta maupun Satpol PP sehingga jarang ditemukan penjualan minuman beralkohol menggunakan gerobak motor ini menjadi salah satu faktor penyebab tingginya angka peredaran minuman beralkohol di kota Pekanbaru.

$\begin{array}{llll}\text { Dengan } & \text { begitu terlihat } & & \text { melakukan beberapa kegiatan seperti } \\ \text { secara jelas kinerja Polresta } & \text { sosialisasi ke sekolah-sekolah yang } \\ \text { Pekanbaru dan Satpol PP tidak } & \text { ada di Kota Pekanbaru, } \\ \text { maksimal dalam meminimalisir } & \text { melaksanakan Razia Rutin (Cipta } \\ \text { penjualan maupun peredaran } & \text { Kondisi) di warung remang-remang } \\ \text { minuman beralkohol di Kota } & \text { dan tempat hiburan yang ada di Kota } \\ \text { Pekanbaru. Dilihat dari sudut } & \text { Pekanbaru untuk menanggulangi } \\ \text { pandang kebijakan kriminal dalam } & \text { penjualan dan peredaran minuman } \\ \text { upaya pendekatan melalui Penal } & \text { beralkohol sembarangan. Namun, } \\ \text { (Undang-undang, Peraturan Daerah ) } & \text { upaya tersebut dinilai belum } \\ \text { pihak Polresta dan Satpol PP } & \text { maksimal, dilihat dari sudut pandang } \\ \text { mengaku tidak mengetahui isi dari } & \text { kebijakan kriminal terdapat } \\ \text { undang-undang tentang minuman } & \text { kesenjangan } & \text { dalam } \\ \text { beralkohol, kemudian Satpol PP juga } & \text { pencegahan yang di lakukan oleh } \\ \text { mengatakan bahwa peraturan daerah } & \text { pihak Polresta dan Satpol PP Kota } \\ \text { yang mengatur minuman beralkohol } & \text { Pekanbaru. Dimana Polresta dan } \\ \text { di kota pekanbaru sudah vakum } & \text { Satpol PP hanya memaksimalkan } \\ \text { dalam kurun waktu beberapa tahun } & \text { dari segi pendekatan Non penal saja, } \\ \text { belakangan. Pihak Polresta dan } & \text { seharusnya pihak Polresta dan Satpol } \\ \text { Satpol PP juga tidak pernah } & \text { PP harus memaksimalkan kedua }\end{array}$


pendekatan tersebut untuk

mewujudkan keamanan,

kenyamanan, dan kesejahteraan

sosial dalam masyarakat.

\section{DAFTAR PUSTAKA}

\section{Buku}

Greek, D. C. (2005). Visual Criminology: Using Photography as an Ethnographic Research Method in Criminal Justice Settings. School of Criminology and Criminal Justice Florida State University, 2-10.

Hermasnyah,

Adi.2013

"Penanggulangan Kejahatan Dengan Pidana Badan Di Indonesia Crime Prevention By Physical Punishment In Indonesia". Banda Aceh: Jurnal Ilmu Hukum. No 60:184

Hisyam, Ciek Julyati, 2018, Perilaku Menyimpang : Tinjauan Sosiologis, Penerbit PT Bumi Aksara, Jakarta

Margiyani, Lusi. 2001. Narkoba.Yokyakarta: Media Pressindo

Mustofa, Muhammad, 2010, Kriminologi Edisi Kedua Kajian Sosiologi Terhadap Kriminalitas, Perilaku Menyimpang dan Pelanggaran
Hukum, Penerbit Sari Ilmu Pratama (SIP), Bekasi
Raharjo, Eka. 2009” Upaya Kepolisian Dalam Penanggulangan Kejahatan Perdagangan Anak Di Provinsi Lampung. Jurnal Hukum: 11

Ummah, Khaira, 2017" Peran Polisi Masyarakat (Polmas) Dalam Menangani Perbuatan Akibat Minum Minuman Keras Di Wilayah Hukum Polres Semarang. Semarang: Jurnal Hukum.Vol. 12, No.3:1

Zaidan, M.Ali, 2016, Kebijakan Kriminal, Sinar Grafika, Jakarta

\section{Internet/Website :}

Diakses dari :Wwwriautelevisi.com/2018/11 130 ciu-polsek-tampan-sita puluhan-botol-miras-denganberbagai-merek-dalam-raziawarung -penjual-miras. Diunduh tanggal 08 Desember 2018

Theo Rizky Diakses dari :Pekanbaru.Tribunnewscom./ 2018/06/06.56 -kilogram-sabu 42.700-esstasi-3.412-botolmiras-dimusnakan-dihalamankantor-gubernur-riau.

Diunduh tanggal 08 Desember 2018

Di akses dari :Www.riauposonline/2018/02/1 $\underline{5}$ ciu-ruko-jual-miras-dijalanjuanda-pekanbaru-digrebekpolisi. Diunduh tanggal 08 Desember 2018 